\title{
Microbiology Research Journal International
}

20(5): 1-11, 2017; Article no.MRJl.29564

ISSN: 2456-7043

(Past name: British Microbiology Research Journal, Past ISSN: 2231-0886, NLM ID: 101608140)

\section{Effect of Modified Atmosphere Packaging and Multilayer Flexible Films on pH of Fresh Quail Meat}

\author{
Nazanin Zand ${ }^{1 *}$ and Sharare Jabbari ${ }^{1}$ \\ ${ }^{1}$ Department of Food Science and Technology, Varamin-Pishva Branch, Islamic Azad University, \\ Varamin, Iran. \\ Authors' contributions \\ This work was carried out in collaboration between both authors. Author NZ designed the study, \\ performed the statistical analysis, wrote the protocol, wrote the first draft of the manuscript and \\ managed the literature searches. Authors NZ and SJ managed the analyses of the study and \\ literature searches. Both authors read and approved the final manuscript.
}

Article Information

DOI: $10.9734 / \mathrm{MRJI} / 2017 / 29564$

Editor(s):

(1) Ana Cláudia Coelho, Department of Veterinary Sciences, University of Trás-os-Montes and Alto Douro, Portugal. (2) Hung-Jen Liu, Distinguished professor, Institute of Molecular Biology, National Chung Hsing University, Taiwan

Reviewers:

(1) Chong Leong, Gan, Malaysia. (2) Matheus Poletto, Universidade de Caxias do Sul, Brazil.

(3) Anonymous, Yuzuncu Yil University, Turkey. (4) Harshad Tandel, Narmad South Gujarat University, Surat, India. Complete Peer review History: http://www.sciencedomain.org/review-history/19861

Original Research Article

Received $18^{\text {th }}$ September 2016

Accepted $22^{\text {nd }}$ November 2016

Published $4^{\text {th }}$ July 2017

\section{ABSTRACT}

Aim: In this study, the effect of different concentrations of three gas mixture (Carbon dioxide, Nitrogen, Oxygen), and also vacuum and ordinary conditions and using different flexible multi-layer pouches were studied for evaluating $\mathrm{pH}$ changes of quail meat at $\left(4^{\circ} \mathrm{C}\right)$.

Methodology: Ordinary conditions (control conditions) were compared with four types of modified atmosphere packaging: $\left(\mathrm{N}_{2} 70 \%+\mathrm{CO}_{2} 30 \%\right),\left(\mathrm{N}_{2} 30 \%+\mathrm{CO}_{2} 70 \%\right),\left(45 \% \mathrm{CO}_{2}+45 \% \mathrm{~N}_{2}+10 \% \mathrm{O}_{2}\right)$, and vacuum conditions. Samples of quail meat were packaged in flexible multilayer pouches under modified atmosphere packaging, 3-layer $\left(\mathrm{PET}_{(12)} / \mathrm{AL}_{(12)} / \mathrm{LLD}_{(100)}\right)$, 4-layer $\left(\mathrm{PET}_{(12)} / \mathrm{AL}_{(7)} / \mathrm{PET}_{(12)} / \mathrm{LLD}_{(100)}\right)$, and 3-layer ( $\left.\mathrm{PET}_{(12)} / \mathrm{AL}_{(7)} / \mathrm{LLD}_{(100)}\right)$, in different times during 16 days, with 15 treatment, 3 run. Statistical analysis and comparison of data, were done by software SPSS (Ver: 22) and Duncan's new multiple range test, with confidence level of $95 \%(P<0.05)$. Results: Packed samples were performed chemical test ( $\mathrm{pH}$ test). The changes of $\mathrm{pH}$ in fresh 
samples were not acceptable under $\% 30 \mathrm{CO}_{2}$ and also vacuum conditions in these containers. However, the best conditions belonged to $\mathrm{CO}_{2} 70 \%$, and then $\mathrm{CO}_{2} 45 \%$, that were acceptable. Packed samples in 4-layer under gas combination $\mathrm{CO}_{2} 70 \%$ had best results.

Conclusion: Protection of these meats in 4-layer container was better than 3-layer container because the steam permeability of 4-layer was lower than 3-layer and also increasing $\mathrm{CO}_{2}$ could not adversely effect on $\mathrm{pH}$, and postponed the $\mathrm{pH}$ changes and preserving quail meat till 16 days.

Keywords: Modified atmosphere packaging; $\mathrm{pH}$; quail meat; flexible multi-layer films.

\section{INTRODUCTION}

Today poultry meat as a white meat with lower risks than red meat, is used more than, and have a large role in the growth of food productions so can be replaced by other sources of animal protein. High growth rate in poultry industry, appropriate feed conversion ratio, the nutritional value of chicken meat, the proportion of amino acids contained in it, Low cholesterol, lower diseases transmitted to humans from this meat than red meat, good taste, etc... has led poultry meat to be placed more and more in household food $[1,2,3,4,5]$. Due to the increasing level of rigor in science and amount of food hygiene and safety of fresh meat processed and the need to produce with minimal costs and Supplying customers' demands, Food packaging industry, especially in the case of meat and meat products rapidly development. USA is largest producer and exporter of chicken meat, countries such as Brazil, Europe and Thailand are the main rivals for export [6]. In terms of zoology quail belongs to chicken family, and in general, two species are highly regarded European and Japanese quail that among these two species there is a close relationship. Japanese quail are wild birds in pairs are living in the summer in the north and in winter in the southern part of the island Japanese [7]. While European quail widely distributed in Europe, Siberia, Iran, Turkey, China and Egypt. However, there are many similarities between European and Japanese quail and the only difference is in size of body Quail meat is delicious, tasty and nourishing. Fresh quail meat can be stored in the refrigerator for two days [7]. The main characteristic of this meat contain rich in omega-3, Iron / vitamins A, B, C / Amino Acids, increasing body resistance, strengthening muscles and bones, and due to the low volume and high levels of protein than eggs, quail eggs, is recommended for athletes, particularly body builders [7]. Modified Atmosphere Packaging (MAP) is a useful technique for various researches. However, it is well known that there is a non-thermal method for inactivation microorganism, which is widely used for shelf- life prolongation, and improvement the quality of perishable foodstuffs such as meat, fishery and vegetable $[8-10,11]$, and also there is no degradation of flavor and taste with heat denaturation of objectives [12,13,2,3,14-16]. The ability of modified-atmosphere packaging for extending the shelf life of foods has been recognized for many years. Indeed, over 100 years ago [10,17,18]. Modified atmosphere packaging is the enclosure of a food, in a package in which the atmosphere has been changed by altering the proportions of carbon dioxide, oxygen, nitrogen, water vapor and trace gases. The process limits microorganism as well as biochemical activity. This modification is performed by gas flash packaging which oxygen is removed and replaced by controlled gas compositions $[9,1,4,5,19,20]$. MAP inhibits some microorganisms, so can increase the quality of variety foods. However the growth of microorganisms depends on temperature, $\mathrm{pH}$ and water activity as the main growthdetermining factors, other factors can significantly influence the growth characteristics of the microorganism. All mentioned in this study include the initial CO2/N2/O2 concentration (\%) in the head space of pouches as the independent variable for the gas atmosphere demonstrated that $\mathrm{CO} 2$ exerts as an antimicrobial effect in the water-phase of the food product $[13,17,2,3,14]$, therefore except the effect of intrinsic, extrinsic and processing parameters on the $\mathrm{CO} 2$ solubility, the concentration of dissolved $\mathrm{CO} 2$ in the waterphase of the food product should be incorporated in this study as independent variable $[10,21,22]$. Nitrogen (N2) is a non-reactive gas that has no smell or taste, unlike carbon dioxide, is not absorbed in food or water $[23,1,4,5,19,20]$. It is used as a filler gas to replace oxygen and thus prevent spoilage or to replace carbon dioxide and prevent package collapse and also oxygen (O2) prevents anaerobic bacteria growth $[21,24,4,5,19,20]$. The most common packages that have been usually used for poultry, are individual pouches formed from polymer layers or plastic layers such as polyethylene (LLD), and 
polyethylene terephthalate (PET), which are barrier films and also have a metal layer such as aluminum [25,26,27-29,30,4,5,19,20]. The main goals of this study include, first, investigation about the effects of modified atmosphere packaging with different concentrations of $\mathrm{CO} 2 / \mathrm{N} 2 / \mathrm{O} 2$, and vacuum on $\mathrm{pH}$ changes $[1,4,5,19,20]$, and second using three multilayer flexible films $[1,31,4,5,19,20]$ for packaging quail meat during storage times (16 days) and controlling $\mathrm{pH}$ of this meat too. We want to prove MAP can substitute thermal processing in conservation industries, and control $\mathrm{pH} 1$ $[32,31,4,5,19,20]$.

\section{MATERIALS AND METHODS}

\subsection{Preparation of Packed Quail}

Quails (0.5 kg weight) were chosen for this experiment bought from local supermarket in Tehran-Iran. These samples were washed, bones were removed and cut to slices $(5 \mathrm{~cm}$ * 5 $\mathrm{cm})$. Temperature was controlled in order to decrease to ambient temperature $\left(T=25^{\circ} \mathrm{C}\right)$. Samples were ready for packaging, pouches contain $40 \mathrm{~g}$ fresh quails $[1,4,5,19,20]$. Analytical parameters such as $\mathrm{pH}$ (Crison $2001 \mathrm{pH}$ meter; Crison Instruments, SA, Barcelona, Spain) soluble solid content (Atago $\mathrm{RX}-1000$ refract meter; Atago Company Ltd., Japan), were measured according to the ISIRI regulation [32,33].

\subsection{Modified Atmosphere Packaging}

Henkelman packing machine (Boxer-200A) was used in this project as shown in Fig. 1. Samples were packed into 3 types of multilayer flexible pouches, 3-layer (PET(12)/AL(12)/LLD(100)), 4layer (PET(12)/AL(7)/PET(12)/LLD(100)), and 3layer (PET(12)/AL(7)/LLD(100)), under modified

atmosphere. Samples were ready for gas injection. Different gas compositions (\%30 N2 and \%70 $\mathrm{CO} 2)$, (\%70 $\mathrm{N2}$ and \%30 $\mathrm{CO} 2)$, $(45 \% \mathrm{CO} 2+45 \% \mathrm{~N} 2+10 \% \mathrm{O} 2)$ and vacuum were transferred from modified atmosphere packaging machine. After packaging, samples were put in refrigerator immediately, for evaluation $\mathrm{pH}$ changes in different treatments [1,26,27-29, $30,34,4,5,19,20]$.

\subsection{Chemical Tests}

\subsubsection{Evaluation of $\mathrm{pH}$}

$\mathrm{PH}$ meter was adjusted with a buffer solution to 4 -7. Sample $(100 \mathrm{~g})$ was uniformed, and poured into $100 \mathrm{ml}$ Erlenmeyer flask and $\mathrm{pH}$ has been measured at ambient temperature $\left(\mathrm{T}=2^{\circ} \mathrm{C}\right)[32,33,1,4,5,19,20]$.

\subsection{Samples Packaging and Storage}

All pouches (unprocessed and processed samples), were put at refrigerator temperature $\left(T=4^{\circ} \mathrm{C}\right)$. Quail meat were packaged into three multilayer type of flexible pouches. Analytical characteristics of these barrier containers were shown in Table $1[1,26,27-29,30,34,4,5$, 19,20].

\subsection{Statistical Analysis}

In order to describe the variables of this experiment, we must design a model to analysis relationship between type of samples, type of treatments, $\mathrm{pH}$ amounts. Statistical analysis of the data gained in this study, was performed by Statistical Package For Social Science (SPSS Ver:22) with ANOVA test, and comparison of data was done by Duncan's new multiple range test, with confidence level of $95 \%$ $[1,4,5,19,20]$.

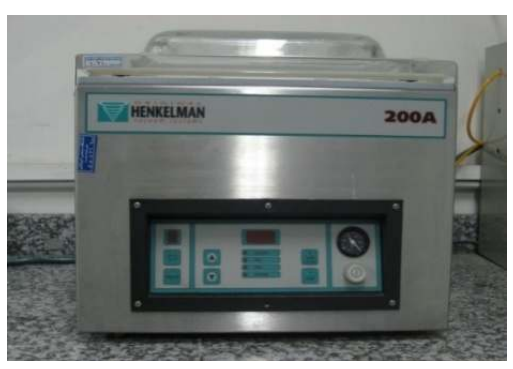

(A)

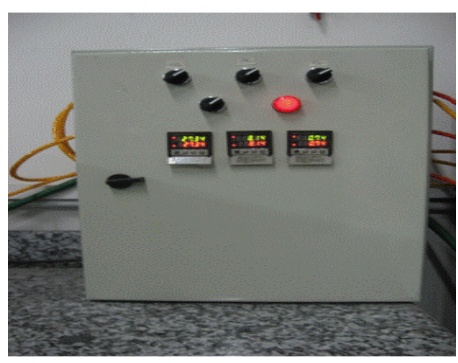

(B)

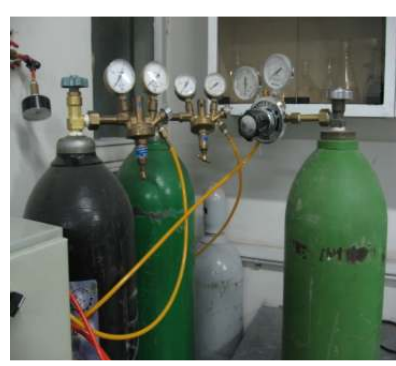

(C)

Fig. 1. (A) Modified atmosphere packaging, (B) Gas analyzer, (C) Gas mixer $[1,4,5,19,20]$ 
Table 1. Analytical characteristics of containers $[1,26,27-29,30,34,4,5,19,20]$

\begin{tabular}{llllll}
\hline Sample & Layers & $\begin{array}{l}\text { Thickness } \\
(\boldsymbol{\mu})\end{array}$ & $\begin{array}{l}\text { Tensile of } \\
\text { sealing film }(\mathbf{N})\end{array}$ & $\begin{array}{l}\text { O.T.R } \\
\mathbf{m l} / \mathbf{m} 2 . \text { day }\end{array}$ & $\begin{array}{l}\text { W.V.T.R } \\
\mathbf{g} / \mathbf{m} \text { 2.day }\end{array}$ \\
\hline PET/AL/LLD & $12 / 12 / 100$ & 124 & 58.88 & 0 & 0.11 \\
PET/AL/LLD & $12 / 7 / 100$ & 119 & 48.89 & 0 & 0.50 \\
PET/AL/PET/LLD & $12 / 7 / 12 / 100$ & 131 & 61.03 & 0 & 0.089 \\
\hline
\end{tabular}

PET: Poly Ethylene Terephthalate; LLD: Low Density Poly Ethylene; AL: Aluminum

\section{RESULTS}

According to analysis of variance Table 2, the effect of different containers, gas compositions, times and the double interactions (layer, gas), (layer, time), and (gas, time) and the triple interaction (layer, gas, time) on $\mathrm{pH}$ were significant differences $(p<0.01)$. The primary effects of containers, gas compositions and times on $\mathrm{pH}$ were significant at $\% 1$.
According to Table 3 and Fig. 2, there was a significant difference between 3-layer, PET (12)/AL (12)/LLD (100), 4-layer, PET (12)/AL (7)/PET (12)/LLD (100), and 3-layer, PET (12)/AL (7)/LLD (100), on $\mathrm{pH}(\mathrm{P} \leq 0.05)$. Results were showed that with 3-layer (AL:7), $\mathrm{pH}$ was higher than other containers, but The best condition belonged to 4-layer with lowest $\mathrm{pH},(\mathrm{P} \leq 0.05)$ due to the thickness $(131 \mu)$, low permeability of water vapor in this 4-layer container.

Table 2. Analysis of variance mean squares traits in response to treatments

\begin{tabular}{|c|c|c|c|c|c|}
\hline Resource (Variable) & $\begin{array}{l}\text { (SS) } \\
\text { Total } \\
\text { square }\end{array}$ & $\begin{array}{l}\text { (Df) } \\
\text { Fredom } \\
\text { degree }\end{array}$ & $\begin{array}{l}\text { (MS) } \\
\text { Average } \\
\text { square }\end{array}$ & $\begin{array}{l}\text { (F) } \\
\text { Variance }\end{array}$ & $\begin{array}{l}\text { (P) } \\
\text { Error }\end{array}$ \\
\hline Container $(\mathrm{C})$ & 0.410 & 2 & 0.205 & $5.286^{* *}$ & 0.006 \\
\hline Gas composition (A) & 2.728 & 4 & 0.682 & $17.597^{* *}$ & 0.000 \\
\hline Time $(Z)$ & 7.277 & 3 & 2.426 & $62.582^{* *}$ & 0.000 \\
\hline $\begin{array}{l}\text { Container * Gas composition } \\
\left(C^{*} A\right)\end{array}$ & 0.022 & 8 & 0.003 & $0.072 \mathrm{~ns}$ & 1.000 \\
\hline Container * Time $\left(C^{*} Z\right)$ & 0.009 & 6 & 0.002 & $0.039 \mathrm{~ns}$ & 1.000 \\
\hline Gas composition * Time $\left(A^{*} Z\right)$ & 0.313 & 12 & 0.026 & $0.673 \mathrm{~ns}$ & 0.774 \\
\hline $\begin{array}{l}\text { Container }{ }^{*} \text { Gas composition * } \\
\text { Time }^{*}\left(C^{*} A^{*} Z\right)\end{array}$ & 0.028 & 24 & 0.001 & $0.030 \mathrm{~ns}$ & 1.000 \\
\hline Error & 4.651 & 120 & 0.039 & & \\
\hline Total & 6972.013 & 180 & & & \\
\hline
\end{tabular}

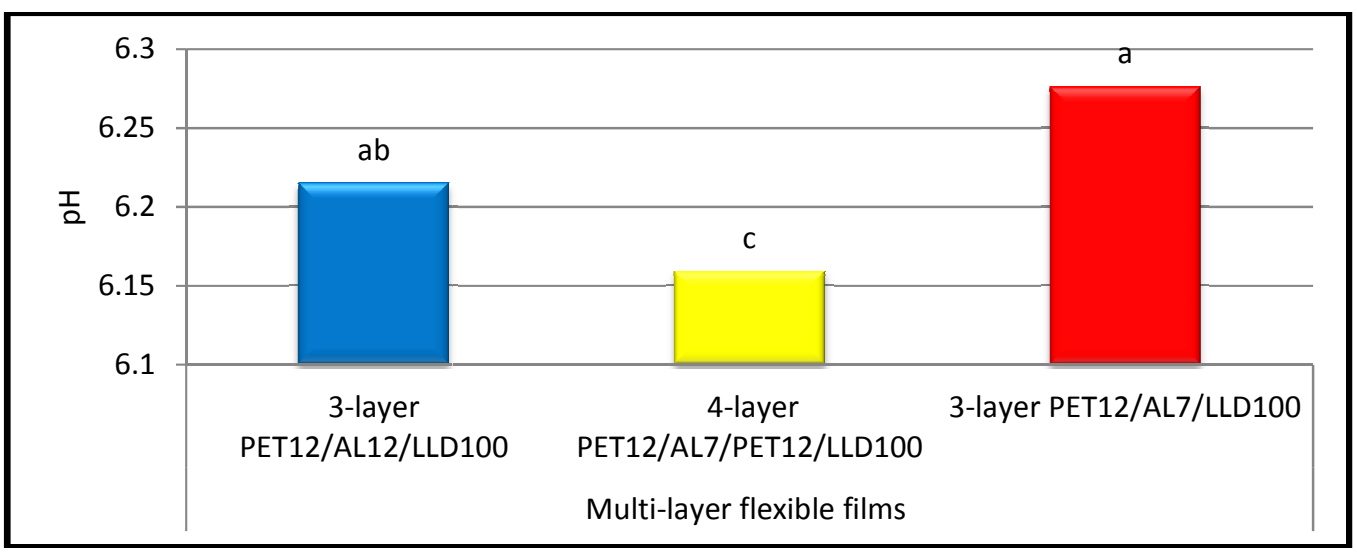

Fig. 2. The effect of different multilayer flexible films on pH (Single interaction) 
According to Table 4 and Fig. 3, there was a significant difference between different gas combinations in $\mathrm{pH}(\mathrm{P} \leq 0.05)$. Results were showed that in ordinary condition (control), $\mathrm{pH}$ was higher than other packaging conditions. The best condition belonged to $70 \% \mathrm{CO} 2+30 \% \mathrm{~N} 2$ with lowest $\mathrm{pH},(\mathrm{P} \leq 0.05)$, lowest amount of $\mathrm{pH}$ due to mechanism could be described by its solution in water of food tissue and produced carbonic acid which the more carbonic acid was decreased $\mathrm{pH}$.

According to Table 5 and Fig. 4, there was a significant difference between different storage times in $\mathrm{pH}(\mathrm{P} \leq 0.05)$. Results were showed that after 16 days, $\mathrm{pH}$ was higher than other days. The best condition belonged to day 4 with lowest $\mathrm{pH}, \quad(\mathrm{P} \leq 0.05)$, which caused to grow microorganisms by the times and changed $\mathrm{pH}$.

According to Table 6 and (Fig. 5a, b, c, d), the amount of $\mathrm{pH}$ in different pouches were observed in different storage times $(4,8,12,16$ days), the highest amount of $\mathrm{pH}$ belonged to $\mathrm{C} 3 \mathrm{~A} 5$, which was fresh quail samples with 3-layer pouch, PET (12)/AL (7)/LLD (100) in control condition. The lowest amount of $\mathrm{pH}$ belonged to $\mathrm{C} 2 \mathrm{~A} 1$ in 4-layer pouch, PET (12)/AL (7)/PET (12)/LLD (100) under gas condition $70 \% \mathrm{~N} 2+30 \% \mathrm{CO} 2$. The variables were shown by different letter in each column had not significantly level with others $(\mathrm{P} \leq 0.05)$.

Table 3. The effect of different multilayer flexible films on $\mathrm{pH}$

\begin{tabular}{ll}
\hline Multilayer flexible films & pH amount \\
\hline $\begin{array}{l}\text { 3-layer, PET (12)/AL } \\
\text { (12)/LLD (100) }\end{array}$ & $6.215 \pm 0.296 \mathrm{ab}$ \\
$\begin{array}{l}\text { 4-layer, PET (12)/AL } \\
\text { (7)/PET (12)/LLD (100) }\end{array}$ & $6.159 \pm 0.296 \mathrm{c}$ \\
$\begin{array}{l}\text { 3-layer, PET (12)/AL (7)/LLD } \\
\text { (100) }\end{array}$ & $6.276 \pm 0.282 \mathrm{a}$ \\
\hline
\end{tabular}

Table 4. The effect of different packaging conditions on $\mathrm{pH}$

\begin{tabular}{ll}
\hline Packaging conditions & pH amount \\
\hline $70 \% \mathrm{CO} 2+30 \%$ & $6.048 \pm 0.279 \mathrm{~d}$ \\
$\mathrm{~N} 2$ & \\
$30 \% \mathrm{CO} 2+70 \% \mathrm{~N} 2$ & $6.203 \pm 0.268 \mathrm{bc}$ \\
$45 \% \mathrm{CO} 2+45 \% \mathrm{~N} 2+10 \% \mathrm{O} 2$ & $6.149 \pm 0.279 \mathrm{c}$ \\
Vacuum conditions & $6.264 \pm 0.232 \mathrm{~b}$ \\
Control & $6.417 \pm 0.284 \mathrm{a}$ \\
\hline
\end{tabular}

Table 5. The effect of different storage times on $\mathrm{pH}$

\begin{tabular}{ll}
\hline Storage time (day) & $\mathbf{p H}$ amount \\
\hline 4 & $5.942 \pm 0.210 \mathrm{~d}$ \\
8 & $6.115 \pm 0.227 \mathrm{c}$ \\
12 & $6.351 \pm 0.192 \mathrm{~b}$ \\
16 & $6.457 \pm 0.228 \mathrm{a}$ \\
\hline
\end{tabular}

As you see in Fig. 6, kinetics of $\mathrm{pH}$ of fresh quail meat during storage times was showed according to this figure, $\mathrm{pH}$ in all conditions followed a similar pattern and had a significant difference over storage times $(p \leq 0.05)$, the conclusion showed that the triple interaction between different layers, different composition of gases in different times on $\mathrm{pH}$ had increased slower in gas composition 1 (\% $30 \mathrm{~N} 2+\% 70$ CO2) and 4-layer ,and had the best effect on $\mathrm{pH}$ changes, over the time, and amount of $\mathrm{pH}$ were in limit, that was not increased rapidly, then 4-layer and gas compositions (\% $45 \mathrm{~N} 2+\%$ $45 \mathrm{CO} 2+\% 10 \mathrm{CO} 2)(\% 70 \mathrm{~N} 2$ + \% $30 \mathrm{CO} 2)$ and 4- layer and vacuum had been affective ,so the shelf life according to $\mathrm{pH}$ changes had evaluated, 16,15,14 days under gas combination $1,2,3$ and vacuum conditions 12 days. Samples were packed in 3-layer (AL: 12 ) was acceptable after 14,12,10 days under gas combination 1,2,3 and after 8 day in vacuum .But in 3-layer (AL: 7) was reported $11,10,8$ days under gas combinations $1,2,3$ and 6 days in vacuum condition .The usage of container with greater thickness and less steam permeability ,and the gas composition with higher amount of $\mathrm{CO} 2$ (gas composition 1) was more effective and had the best inhibitory effect on $\mathrm{pH}$ changes.

\section{DISCUSSION}

In this study, the best condition was belonged to samples in 4-layer container under $(70 \%$ CO2) which controlled $\mathrm{pH}$ of quail meat till 16 days. Protection of these samples in 4-layer was better than two types of 3-layer containers $\{(A L: 12) \&$ (AL: 7)\}, because the steam permeability of 4layer was lower than 3-layer pouches, so the usage of this packaging was better for preserving quail meat in long time. The lowest amount of $\mathrm{pH}$ was belonged to 4-layer, under $70 \% \mathrm{CO} 2+30 \%$ $\mathrm{N} 2$, and the highest amount of $\mathrm{pH}$ observed in 3layer (AL: 7) with ordinary condition. These parameters were evaluated according to the National Standard of Iran (ISIRI 2326). The modified atmosphere packaging (MAP) was not lead to stop spoilage completely. The effect of MAP was not adequate but using this technique 
inactivated microorganism and controlled chemical reactions such as $\mathrm{pH}$. The best shelf life of quail fresh meat in ordinary condition at refrigerator $\left(T=4^{\circ} \mathrm{C}\right)$ was 2 days. According to these results $\mathrm{pH}$ could be controlled after 16 days for condition $70 \% \mathrm{CO} 230 \%$ N2. Changes of $\mathrm{pH}$ in various conditions, had significant differences between (layer, gas) (layer, time) and also (gas, time) $(\mathrm{P}<0.01)$.

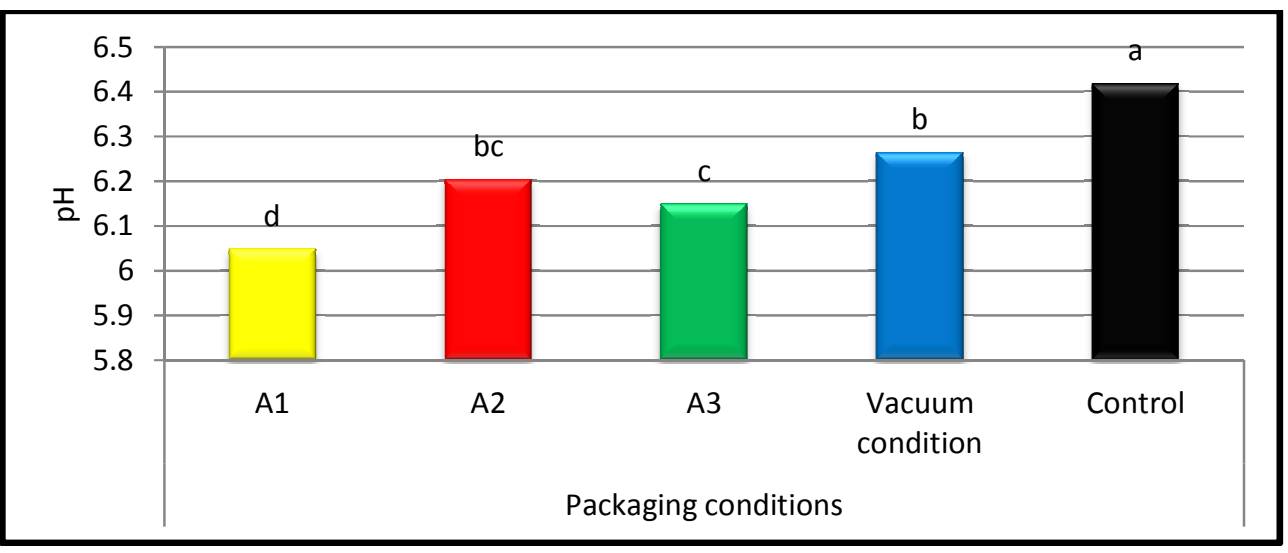

Fig. 3. The effect of different packaging conditions on $\mathrm{pH}$ (Single interaction)

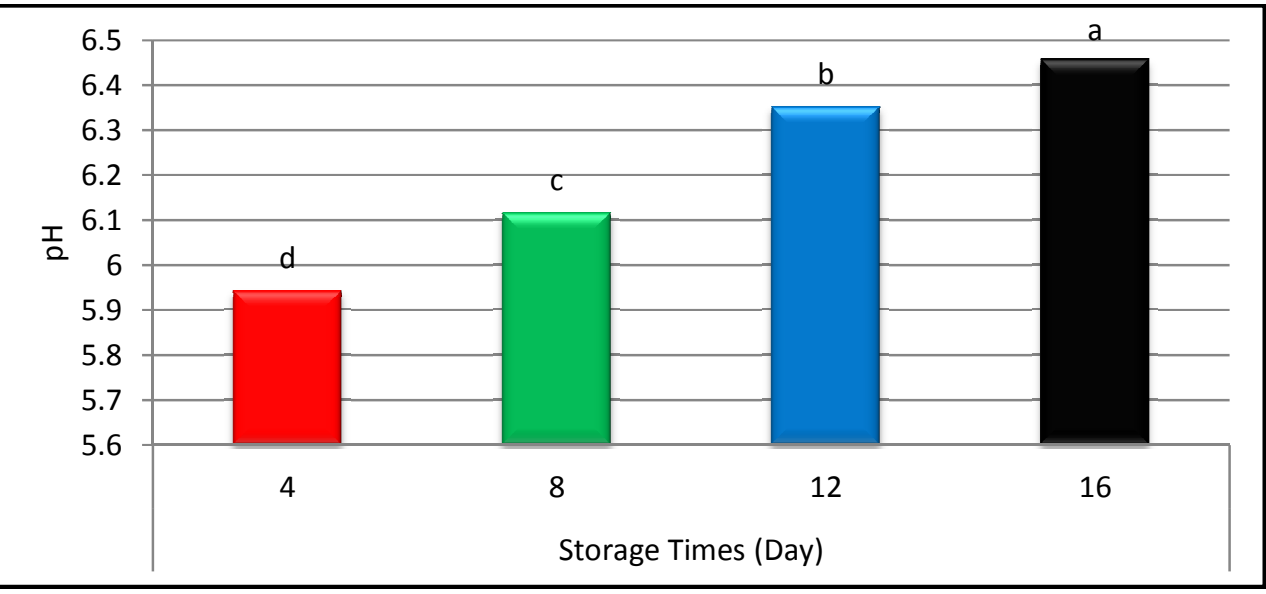

Fig. 4. The effect of different storage times on pH (Single interaction)

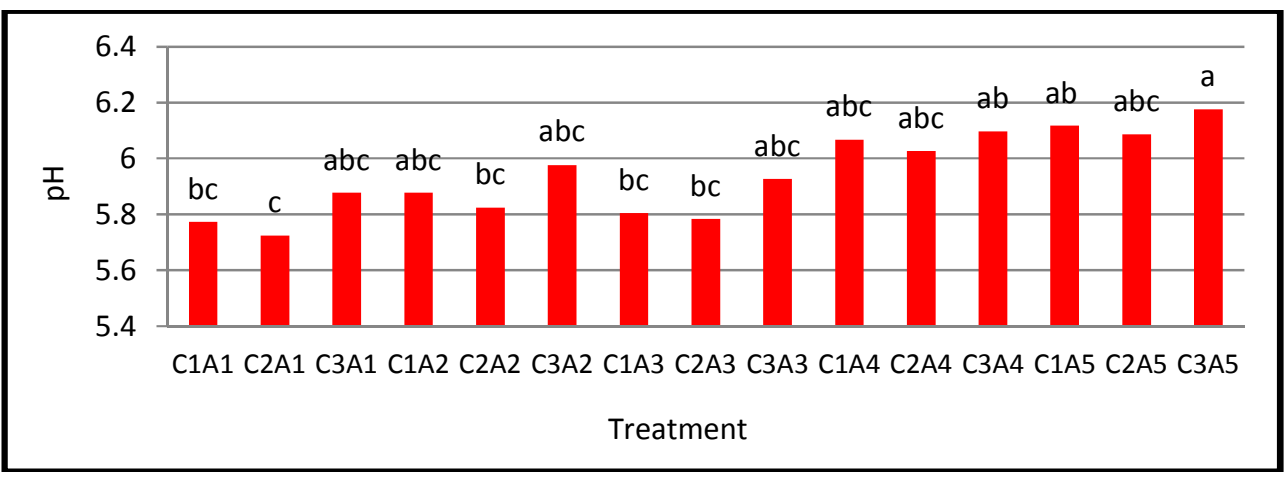

Fig. 5a. Amount of pH under different treatments after $\mathbf{4}$ days (Double interaction) 


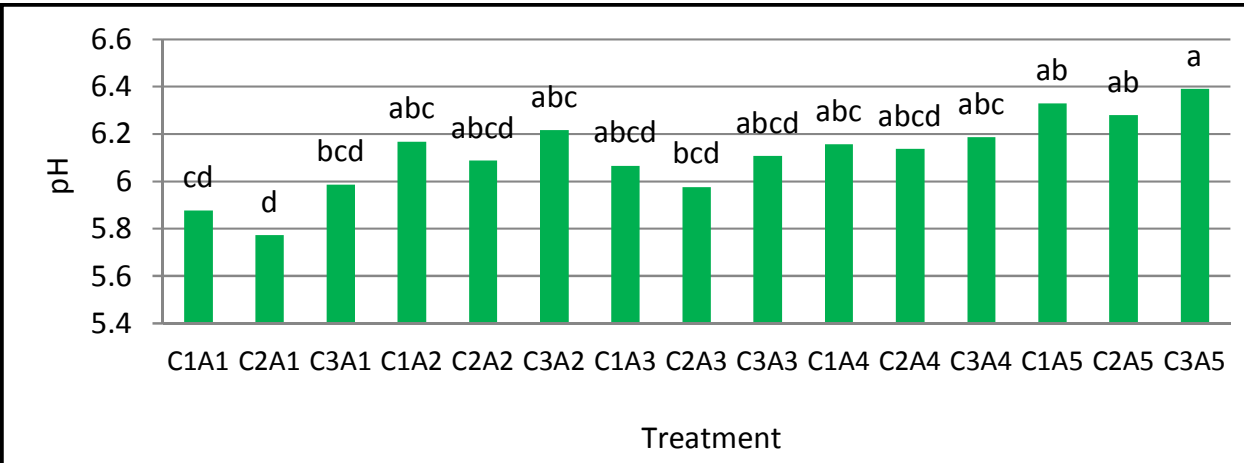

Fig. 5b. Amount of $\mathrm{pH}$ under different treatments after 8 days (Double interaction)

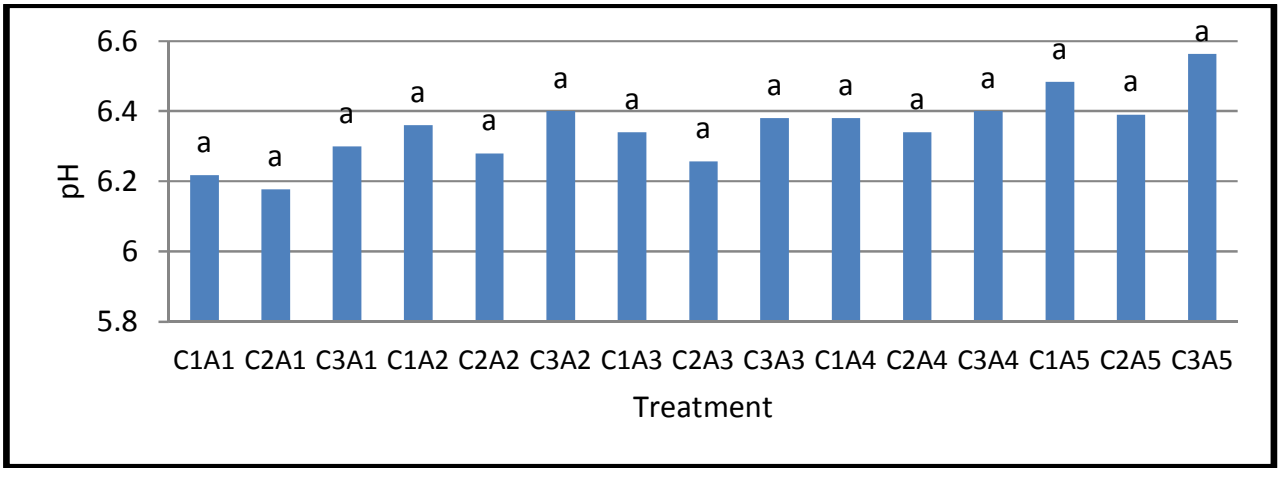

Fig. 5c. Amount of pH under different treatments after 12 days (Double interaction)

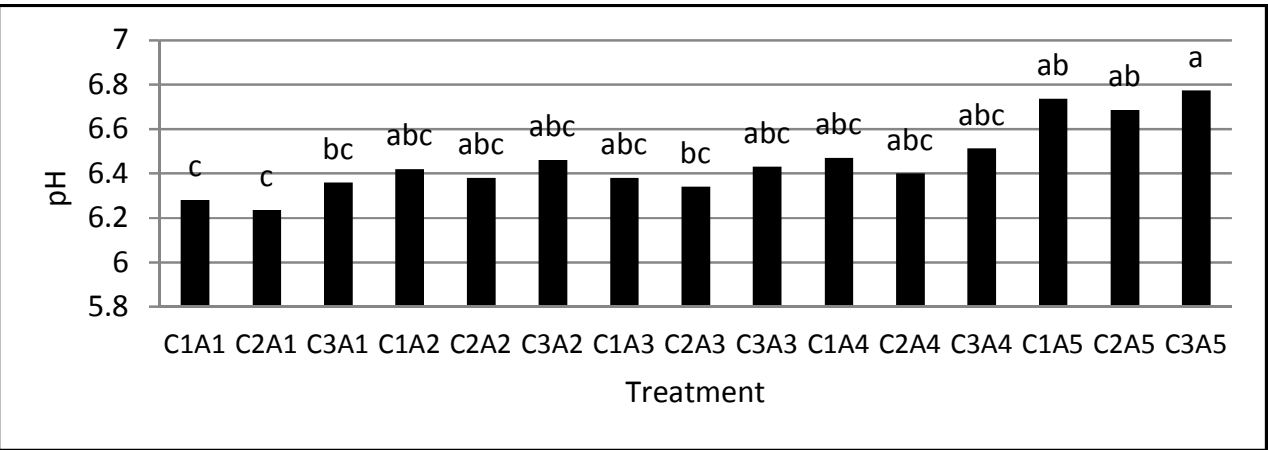

Fig. 5d. Amount of pH under different treatments after 16 days (Double interaction)

Table 6. Amount of $\mathrm{pH}$ in different treatments during different days

\begin{tabular}{lllll}
\hline Treatment & Day 4 & Day 8 & Day 12 & Day 16 \\
\hline C1A1 & $5.773 \pm 0.181 \mathrm{bc}$ & $5.876 \pm 0.187 \mathrm{~cd}$ & $6.216 \pm 0.196 \mathrm{a}$ & $6.280 \pm 0.202 \mathrm{c}$ \\
C2A1 & $5.723 \pm 0.181 \mathrm{c}$ & $5.773 \pm 0.181 \mathrm{~d}$ & $6.176 \pm 0.196 \mathrm{a}$ & $6.236 \pm 0.196 \mathrm{c}$ \\
C3A1 & $5.876 \pm 0.181 \mathrm{abc}$ & $5.986 \pm 0.187 \mathrm{bcd}$ & $6.300 \pm 0.202 \mathrm{a}$ & $6.360 \pm 0.202 \mathrm{bc}$ \\
C1A2 & $5.876 \pm 0.181 \mathrm{abc}$ & $6.166 \pm 0.196 \mathrm{abc}$ & $6.360 \pm 0.202 \mathrm{a}$ & $6.420 \pm 0.202 \mathrm{abc}$ \\
C2A2 & $5.823 \pm 0.181 \mathrm{bc}$ & $6.086 \pm 0.196 \mathrm{abcd}$ & $6.280 \pm 0.196 \mathrm{a}$ & $6.380 \pm 0.202 \mathrm{abc}$ \\
C3A2 & $5.976 \pm 0.181 \mathrm{abc}$ & $6.216 \pm 0.196 \mathrm{abc}$ & $6.400 \pm 0.202 \mathrm{a}$ & $6.460 \pm 0.202 \mathrm{abc}$ \\
C1A3 & $5.803 \pm 0.181 \mathrm{bc}$ & $6.066 \pm 0.187 \mathrm{abcd}$ & $6.340 \pm 0.202 \mathrm{a}$ & $6.380 \pm 0.202 \mathrm{abc}$ \\
C2A3 & $5.783 \pm 0.181 \mathrm{bc}$ & $5.976 \pm 0.187 \mathrm{bcd}$ & $6.256 \pm 0.196 \mathrm{a}$ & $6.340 \pm 0.202 \mathrm{bc}$ \\
\hline
\end{tabular}




\begin{tabular}{lllll}
\hline Treatment & Day 4 & Day 8 & Day 12 & Day 16 \\
\hline C3A3 & $5.926 \pm 0.181 \mathrm{abc}$ & $6.106 \pm 0.196 \mathrm{abcd}$ & $6.380 \pm 0.202 \mathrm{a}$ & $6.430 \pm 0.202 \mathrm{abc}$ \\
C1A4 & $6.066 \pm 0.181 \mathrm{abc}$ & $6.156 \pm 0.196 \mathrm{abc}$ & $6.380 \pm 0.202 \mathrm{a}$ & $6.470 \pm 0.202 \mathrm{abc}$ \\
C2A4 & $6.026 \pm 0.181 \mathrm{abc}$ & $6.136 \pm 0.196 \mathrm{abcd}$ & $6.340 \pm 0.202 \mathrm{a}$ & $6.400 \pm 0.202 \mathrm{abc}$ \\
C3A4 & $6.096 \pm 0.196 \mathrm{ab}$ & $6.186 \pm 0.196 \mathrm{abc}$ & $6.400 \pm 0.202 \mathrm{a}$ & $6.513 \pm 0.207 \mathrm{abc}$ \\
C1A5 & $6.116 \pm 0.196 \mathrm{ab}$ & $6.330 \pm 0.202 \mathrm{ab}$ & $6.483 \pm 0.207 \mathrm{a}$ & $6.736 \pm 0.213 \mathrm{ab}$ \\
C2A5 & $6.086 \pm 0.196 \mathrm{abc}$ & $6.280 \pm 0.202 \mathrm{ab}$ & $6.390 \pm 0.202 \mathrm{a}$ & $6.686 \pm 0.213 \mathrm{ab}$ \\
C3A5 & $6.176 \pm 0.196 \mathrm{a}$ & $6.390 \pm 0.202 \mathrm{a}$ & $6.563 \pm 0.207 \mathrm{a}$ & $6.773 \pm 0.190 \mathrm{a}$ \\
\hline
\end{tabular}

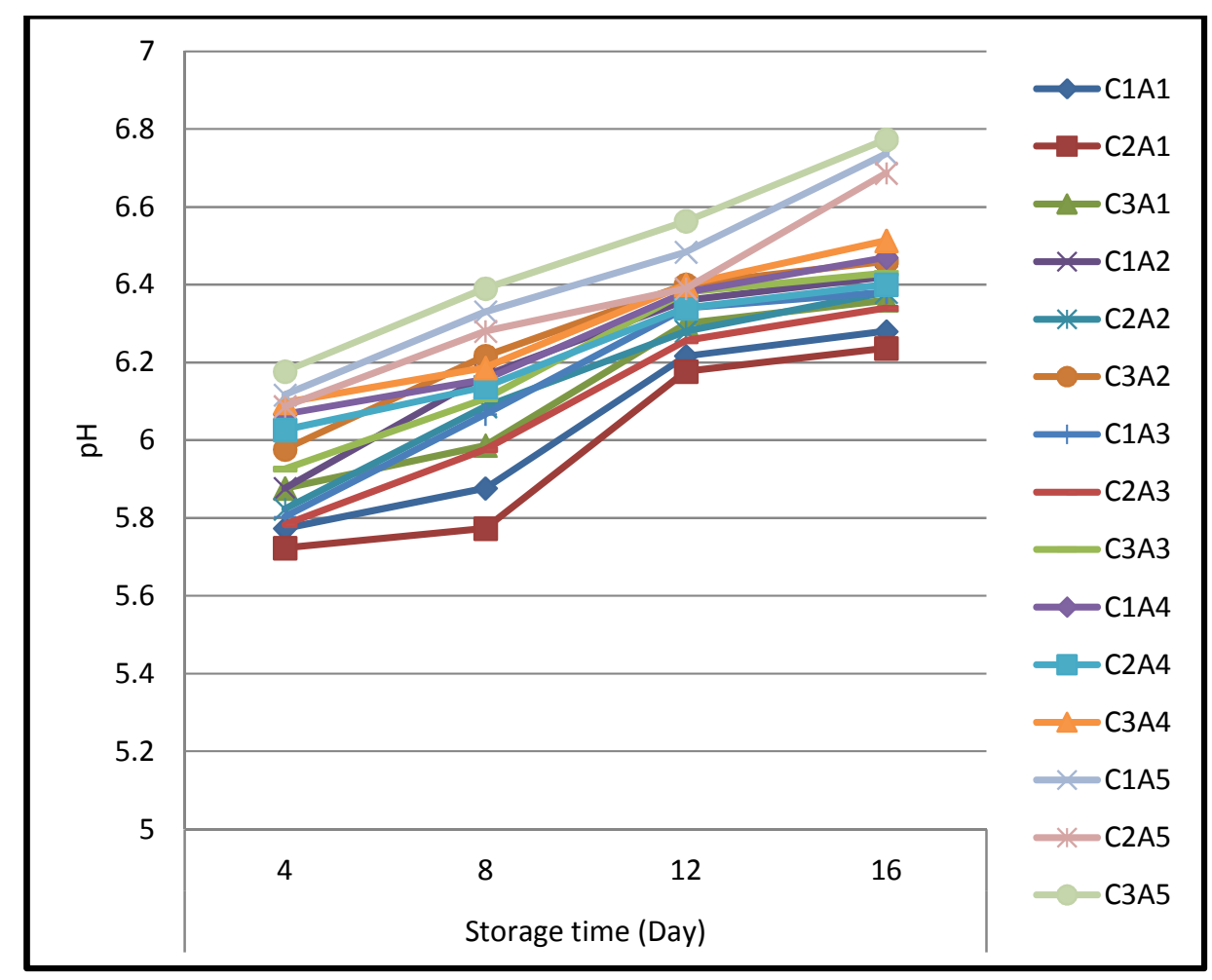

Fig. 6. The effects of storage times, packaging conditions and multilayer flexible films on pH (Triple interaction)

Pexara et al. [25], due to effect of modified atmosphere and vacuum packaging on cooked, sliced turkey fillets and cooked pork sausages at +4 and $+10^{\circ} \mathrm{C}$, the results were similar to these results and reliable. Gill [10] indicated that due to packaging meat under carbon dioxide, the results of this study were acceptable. Ohlsson and Bingtsson [23], due investigation about modified atmosphere packaging, in food industry, the results of this investigation were reliable. Athina et al. [12], indicated that due to formation of biogenic amines and relation to microbial flora and sensory changes in smoked turkey breast fillets stored under various packaging conditions, the results showed that the shelf life of turkey meat under $\% 60 \mathrm{CO} 2$ prolonged till 7 days, were corresponded with this investigation. Chouliara and Karatapanis [9] indicated that due to combined effect of oregano essential oil and modified atmosphere packaging on shelf-life extension of fresh chicken breast meat, the results of $\mathrm{pH}$ changes, were similar to these results. Sotoudeh et al. [1], concluded due to research about usage of MAP for shelf life extension of packed spicy chicken meal in multilayer flexible pouches, 4-layer was better than 3layer during 3 weeks, best condition belonged to $\mathrm{CO} 2 \% 70$, the results were corresponded to these results. Zand and Sotoudeh [4,5], due to effect of packaging under gas combination $\% 30$ $\mathrm{N} 2+\% 70 \mathrm{CO} 2$ in 4- layer flexible films $(131 \mu)$ on shelf life and $\mathrm{pH}$ of chicken meal, was better than 3-layer flexible films (124 $\mu$ ) during 20 days, that the results were similar to this investigation. Zand and Allahyari $[19,20]$, due to research about effect of packaging under gas combination 
$\% 30 \mathrm{~N} 2+\% 70 \mathrm{CO} 2$ in 4-layer flexible films $(131 \mu)$ on shelf life and $\mathrm{pH}$ of candy bread ,was better than 3-layer flexible films $(124 \mu)$ during 20 days, that the results were corresponded with these result. Zand [35], indicated that due to shelf life extension of mushroom meal in multilayer flexible pouches 4-layer container was better than 3-layer container during 2 months, the results were similar to these results. Zand [36], concluded due to the shelf life prolongation of packed vegetables meal in multi-layer flexible pouches, 4-layer container was better than 3layer container during 2 months, the results were corresponded with these results.

\section{CONCLUSION}

In the present study, it was concluded that, $\mathrm{pH}$ changes as a one of important factor of shelf life of packed quail meat have been affected by different flexible multi-layer pouches and different concentrations of three gas mixture (carbon dioxide, nitrogen, oxygen), and also vacuum conditions during 16 days. Our results confirmed, the modified atmosphere packaging (MAP) was not lead to stop spoilage completely but postponed it. The influence of MAP was not adequate but using this technique not only inactivated microorganism, but also had not significant adverse effect on chemical reactions such as $\mathrm{pH}$ changes. These parameters could be promoted substitution of MAP and these barrier containers instead of other traditional packaging in meat industries, due to a lot of privilege for shelf life extension of fresh quail meat in long times.

\section{ACKNOWLEDGEMENTS}

The authors appreciate, Dr. Simin Asadolahi (Department of Food Science and Technology, Faculty of Agriculture, Islamic Azad University, Varamin-Pishva branch, Varamin, Iran), Eng. Hamid Reza Taheri and PMA Com (Plastic Machine Alvan, Tehran-Iran) for supplying equipment's and materials.

\section{COMPETING INTERESTS}

Authors have declared that no competing interests exist.

\section{REFERENCES}

1. Sotoudeh B, Zand N, Tajabadi EM. The usage of MAP for shelf life extension of packed spicy chicken meal. European
Journal of Experimental Biology. 2013;3: 617-623.

2. Zand N, Mailova E, Foroudi F, Voskanyan A. Combination of high frequency electromagnetic fields with pre heat to inactivate mesophil microorganisms of flexible packed cooked chick and cooked chick meal. African Journal of Microbiology Research. 2010a;4(21):2468-2478.

3. Zand N, Mailova E, Foroudi F, Voskanyan A. Sterilization of flexible pouch by high frequency electromagnetic induction, using cooked chick and chick meal. African Journal of Microbiology Research. 2010b. 4(18):2011-2021.

4. Zand N, Sotoudeh B. The effect of MAP and multilayer flexible pouch for shelf life prolongation of chicken meal. European Journal of Zoological Research. 2013a;2(2): 26-33.

5. Zand N, Sotoudeh B. The influence of MAP on sensory properties of chicken meal. Annals of Biological Research. 2013b;4(6): 175-181.

6. Daneshyar M, Ilkhani F. Turkey raising principles. West Azerbaijan University; 2011.

7. Valii N. Quail raising principles. Shahrekord University Publication; 2009.

8. Cameron-Ac et al. Design of modified atmosphere packaging system. Journal of Food Science. 1989;54(6):1413-1416.

9. Chouliara E, Karatapanis A. Combined effect of oregano essential oil and modified atmosphere packaging on shelf-life extension of fresh chicken breast meat, stored at $4^{\circ} \mathrm{C}$. Food Microbiology. 2007; 24:607-617.

10. Gill CO. Packaging meat under carbon dioxide: The CAPTECH system. Proceedings of Industry Day, $34^{\text {th }}$ Int. Cong. Meat Sci. Technol. Livestock and Meat Authority of Queensland, Brisbane, Australia. 2000;76-77.

11. Simpson R, Acevedo S, Almonacid S. Mass transfer of $\mathrm{CO}_{2}$ in MAP systems: Advances for non - respiring foods. Journal of Food Engineering. 2009;92:233239.

12. Athina G, Ntzimani $M$, Evangelos $K$, Paleologos N, loannis N, Savvaidis B, Michael G. Formation of biogenic amines and relation to microbial flora and sensory changes in smoked turkey breast fillets stored under various packaging conditions 
at $4^{\circ} \mathrm{C}$. Food Microbiology. 2008;25(3): 509-517.

13. Mcmilin K. Where is MAP going? A review and future potential of modified atmosphere for meat. Meat Science. 2008; 80:43-65.

14. Zand N, Multi-layer flexible packaging and high frequency electromagnetic field. Annals of Biological Research. 2011a; 2(2):488-501.

Available:www.scholarsresearchlibrary. $\underline{\text { com }}$

15. Zand N. The usage of high frequency electromagnetic field for sterilization of different packed meal. Annals of Biological Research. 2011b;2(3):442-552.

16. Zand N. Sterilization of packed fish meal by electromagnetic induction. Annals of Biological Research. 2011c;2(4):398-407.

17. Jung $H$. Packaging for non-thermal processing of food department of food science university of Manitoba; 2007.

18. Kerry J, Grady M, Hogan S. Current and potential utilization of active and intelligent packaging systems for meat and musclebased products: A review. Meat Science. 2006;74:113-130.

19. Zand N, Allahyari AS. The influence of MAP and different multilayer flexible films on shelf life extension of candy bread. European Journal of Zoological Research. 2013a;2(3): 29-38.

20. Zand N, Allahyari AS. The effect of MAP on sensory evaluation of candy bread. Annals of Biological Research. 2013b;4(7):243-251.

21. Manos A, Ordoñez J, Garcia de G, Fernando B. Growth/survival of natural flora and Aeromonas hydrophila on refrigerated uncooked pork and turkey packaged in modified atmospheres. Food Microbiology. 2000;17(6):657-669.

22. Mortazavi A, Kasshani N, Ziaolhagh $\mathrm{H}$. Food microbiology (WC Frazier). Ferdowsi University Press; 2002.

23. Ohlsson T, Bingtsson N. Modified atmosphere packaging, in: Minimal processing technologies in food industry. Wood Head Publishing Limited, Cambridge, England. 2002;61-80.

24. Ooraikul B, Stilles ME. Modified atmosphere packaging of fruits and vegetables in: Modified atmosphere packaging of food. Ellis Tbr Wood. London. 1991;169-228.

25. Pexara E, Metaxopoulos J, Drosinos EH. Evaluation of shelf life of cured, cooked, sliced turkey fillets and cooked pork sausages-'piroski'-stored under vacuum and modified atmospheres at +4 and $+10^{\circ} \mathrm{C}$. Meat Science. 2002;62(1):3343.

26. Zand N, Mailova E. The study of the barrier properties of the combined films. Annals of Agrarian Science. (Article in Russian) Republic of Georgia. 2009;7(3): 94-95.

27. Zand N, Mailova E. Combined packaging material flexible packs characteristics dependence on changes of components composition and quantity. Processing $s$ of Engineering Academy of Armenia (Article in Russian) Republic of Armenia. 2010a; 7(1):129-132.

28. Zand N, Mailova E. The strength of the weld seams of flexible packages depending on the sealing mode. Agro science. (Article in Russian) Republic of Armenia. 2010b;1-2:73-77.

29. Zand N, Mailova E. The influence of thermal processing on hermit city of flexible packaging, agronomy and agro ecology. (Article in Russian) Republic of Armenia. 2010c;2:96-99.

30. Zand N. Retort flexible pouch substitute for packaging ready to eat meal. Lambert Academic Publishing. Germany. 2011d. Trends in Food Science \& Technology 13. 2002b;319-324.

Available:info@lap-publishing.com

31. Zand N, Mailova E. Retort flexible pouch substitute for packaging ready to eat meal. Lambert Academic Publishing, Germany; 2011d.

32. Institute of Standards and Industrial Research of Iran (ISIRI). Canned foodSpecification and test methods, $1^{\text {st }}$. Revision, Karaj - Iran. 2003;2326.

33. Institute of Standards and Industrial Research of Iran (ISIRI). Low acid canned food-Causes of microbial spoilage, $1^{\text {st }}$. Revision, Karaj - Iran. 2003;3139.

34. Zand N. Correlation of plastic multilayer packaging films mechanicals properties with composition and percentage of their composition. Information technologies and 
management. (Article in Russian) Republic of Armenia. 2011f;1:232-234.

35. Zand N. Sterilization of packed mushroom meal by high frequency electromagnetic field. European Journal of Experimental Biology. 2013a;3(2):598-607.
36. Zand N. Combination of high frequency electromagnetic induction with thermal processing for shelf life prolongation of packed vegetables meal. European Journal of Experimental Biology. 2013b; $3(3): 246-253$.

(c) 2017 Zand and Jabbari; This is an Open Access article distributed under the terms of the Creative Commons Attribution License (http://creativecommons.org/licenses/by/4.0), which permits unrestricted use, distribution, and reproduction in any medium, provided the original work is properly cited.

Peer-review history:

The peer review history for this paper can be accessed here: http://sciencedomain.org/review-history/19861 